\title{
Perucho, Javier (2009) Dinosaurios de papel. El cuento brevísimo en México. México: Ficticia-UNAM.
}

Israel Ramírez Cruz

FFyL-UNAM

Toda reseña es, además de un juicio sobre un libro, una invitación a su lectura. Cuando el libro que motiva la reseña es digno de recomendar, también —colateralmente- se sugiere su compra. En este caso, Dinosaurios de papel. El cuento brevísimo en México de Javier Perucho no sólo es una obra de indispensable lectura para todo aquel interesado en el micro relato mexicano, es también una invitación para que todos aquellos que deseen conocer la historia del género y sus representantes más logrados en nuestro terreno aclaren lagunas y disfruten de un libro que lo mismo ilustra, por la calidad de la investigación, y cautiva, por la amenidad de su pluma.

Pero si esta reseña es justa, no sólo habrá de recomendar la lectura de este libro, sino que considero que la mejor manera de valorar los verdaderos alcances de este volumen es leerlo en conjunto con El cuento jíbaro. Antología del microrrelato mexicano que publicó el propio Perucho en 2006 (en coedición de Ficticia con la Universidad Veracruzana). Al leer los dos volúmenes se tendrá una mejor posición para reconocer la valía del trabajo que se nos brinda en ambas entregas.

En consecuencia con lo expresado anteriormente, un juicio crítico sobre este trabajo demanda no sólo más espacio, sino un diálogo profundo con la bibliografía que se ha publicado sobre la microficción, cuando menos de la bibliografía sobre las obras mexicanas del siglo XX. Es por ello que aquí sólo abordaremos un aspecto de los muchos que se desprenden de este libro: el que atiende la reflexión sobre el origen del género a la luz de lo expresado por Perucho.

Desafortunadamente, quedan por subrayar más prolijamente los resultados de la parte medular del volumen, lo relativo a las estelas del cuento brevísimo en México o para decirlo en otras palabras, del rastreo que del género hace el autor para certificar su vivaz tradición. De esto sólo diremos brevemente que mucho se podrá extraer de la recuperación que se hace de Sergio Golwarz o de Alejandro Jodorowsky; de la vinculación de Monterroso con Max Aub; de la sensibilidad para dimensionar los hallazgos de Julio Torri o del merecido homenaje que se hace de Edmundo Valades.

Pero también el lector podrá constatar la claridad con la que aborda los nuevos derroteros del género; a los autores noveles; aquellos que desde la "centralidad" que les brinda la periferia geográfica son referentes indispensables, 
como Luis Humberto Crosthwaite. Un libro como este, en resumen, no sólo se debe agradecer por la calidad de la información o por la inteligencia de sus juicios, sino también se agradece por la capacidad con la que provoca en lector nuevas maneras de pensar al microrrelato. Esto justamente es lo que me sucedió y lo que me llevó a detenerme, por dar sólo un ejemplo aquí, en el aspecto de la génesis de la ficción breve.

Los años recientes parecen ser -entre otras cosas - el tiempo propicio para la gestación de nuevos géneros, estéticas o corrientes en la literatura. De ahí que se considere que sólo a partir de la modernidad es posible el texto breve. Tal decir está sostenido en aquellos afanes revisionistas que desconocen que la tradición literaria no responde a fechas ni tampoco se explica gracias a la generación espontánea. Más acorde con una posición de historiador literario - la del minucioso que agota las fuentes y las sopesa con buen juicio-, que con la del crítico de efemérides, Javier Perucho nos revela en un muy bien documentado trabajo que el microrrelato no es un género tan reciente como se pensaba al anclarlo por algunos críticos sólo a la posmodernidad. Si, por ejemplo, David Lagmanovih en El microrrelato. Teoría e historia (Palencia, España: Menoscuarto, 2006) traza la estirpe del género desde Charles Baudelaire y sus Petits Poèmes en prose (1869), Javier Perucho compromete la génesis del arte de narrar desde la brevedad con la antigüedad china: "Como tantas imperecederas aportaciones culturales a la humanidad, la microficción nació en China, como la caña de pescar, el tipo móvil, la notación musical o el relato policiaco, objetos útiles en la vida cotidiana o el reino del arte". (15)

Como muestra de ello, nos recuerda los ejemplos del I Ching y el Tao Te King, sólo por citar dos casos. Desde estos remotos orígenes en que el pensador, el poeta y el predicador se entrelazaban en la misma figura, encontramos la brevedad en los textos, la reflexión didáctica, la lección moral o política, los elementos fabulatorios con su animalia, el personaje único, la frescura de la prosa, la epifanía súbita... elementos todos ellos recurrentes en este tipo de textos y que algunos creen hijos de la modernidad.

Por otra parte, en su vertiente occidental, el autor rescata del olvido los Hechos y dichos memorables de Valerio Máximo y las Noches áticas de Aulio Gelio - por mencionar dos casos- donde se encuentra ya la brevedad y la anécdota narrada, todo esto con el ingrediente añadido de lo oral que se ha vestido ya en la escritura.

Este sólo arranque de lo que Perucho nombra "la consagración del género" nos obliga a ser prolijos en la historización de tan apretada escritura. Además, de aquí se desprenden de mi lectura, tres consideraciones valiosas sobre el origen del cuento breve mexicano. Estas son, en forma general, las siguientes. Primero se afirma que el género no pertenece al siglo XX, mucho menos se limita a clausurarlo al registro de lengua española, pues Perucho nos invita a pensar en la tradición clásica, tanto de China como la grecolatina para asentar los inicios de la escritura breve. 
Lauro Zavala—el otro experto del tema en México—en su Minificción mexicana (2003, México: UNAM, ) postula como precursores a Mariano Silva y Aceves, Ricardo Gómez Robelo, Ramón López Velarde, Carlos Díaz Dufoo II, Alfonso Reyes y Francisco Monterde, entre los más viejos. Quizá por tratarse de una de las antologías literarias del siglo XX que publica la UNAM, Zavala se limita a los escritores de la centuria pasada. ¿Pero es que no hay escritura breve en México antes de estos años? Perucho se detiene con gran intuición en este conflicto —aunque mínimamente-, cuando escribe: "La cuentística mexicana breve del siglo XX tiene sus antecedentes más remotos en el periodismo literario de la centuria antepasada" (233). La proposición que agrega Perucho a la discusión del origen del género entonces no sólo es cuestionar su aparición reciente, sino que nos da muestras de que desde el siglo XIX es una escritura vigente. Véase por ejemplo su página 33, donde se menciona, además, el interregno literario que va del virreinato a la vida independiente y en el cual los géneros breves fueron periféricos; son prueba de ello también los deliciosos ejemplos rescatados de la hemerografía decimonónica.

En segundo lugar - y quizá más trascendental para la discusión teórica de la hibridación genérica que hay en el microrrelato- es la cercanía que alude Perucho del microrrelato con las formas literarias orales, ya sea con las literaturas prehispánicas, con las mestizas o con las más antiguas. En este aspecto de lo oral se vincula la tradición popular española con las formas prehispánicas, pero también lo que se desprende de la poesía épica griega y latina que se reactualiza en los tópicos o protagonistas abordados, ya en los personajes de las sirenas o en el linaje heroico clásico que es tan caro en la ficción breve contemporánea.

Este punto amplía también la perspectiva de estudio sobre las formas de escritura cercanas al microrrelato, como la fábula, los dichos orales, las adivinanzas, las leyendas, los refranes, la viñeta, el aforismo.

Por último, una tercera consideración a celebrar es la interesante reflexión que se hace sobre el papel de Marcel Schwob en los precursores del cuento breve en el México del siglo XX. Se rastrea aquí desde lo que de schwobiano hay en Reyes, Torri, Arreola o Valadés, por mencionar sólo algunos de los casos cimeros y fundacionales del género. Perucho apunta que junto a Schwob - La cruzada de los niños y Vidas imaginarias - está la escritura de Aloysius Bertrand con su Gaspar de la noche, obras que desde el estímulo de lo poético y lo narrativo heredaran su noción del texto breve y trabajado a los maestros mexicanos del género.

Queda por comentar con mayor detenimiento - como se dijo atrás- lo relativo a la amplia nómina de escritores que examina Perucho. Desde los nombres ya clásicos para pensar en este tipo de escritura, hasta los más jóvenes o los allegados a México desde la diáspora que por fortuna los hizo radicar en nuestro país. Tenemos así el estudio de las obras de Raúl Renán, José 
Emilio Pacheco, Felipe Garrido, Guillermo Samperio, Ethel Krauze, Rosa Beltrán, Luis Humberto Crosthwaite, Max Aub, Sergio Golwarz y el infantable Monterroso, por sólo enlistar algunos.

Injusto sería de mi parte no subrayar el esmerado cuidado que salta a la vista en la investigación de Javier Perucho, así como la solvencia con que domina el tema y la obra de los autores compendiados. En síntesis, este libro es una grata invitación para aprender más del cuento breve a través de una prosa pulcra y llena de hallazgos. No puedo menos que afirmar que este libro se convertirá en uno de los trabajos indispensables sobre el tema, mismo que no sólo se brinda inteligente para el estudioso, sino también gozoso por la fluidez con que se deja leer. 
Decires es una publicación editada en línea y de libre acceso alojada en <http://www.decires.unam.mx> del Centro de Enseñanza para Extranjeros de la UNAM. Ciudad Universitaria, mayo 2010. El cuidado de la edición estuvo a cargo de: Ariadna G. Vaca Moro. Diseño de interiores y formación tipográfica: Yvetthe $P$. Rendón Rahal.

Diseño de portada: Yvetthe P. Rendón Rahal. 